\title{
Vladimír Helfert ve Státním ústavu pro lidovou píseň
}

\section{Vladimír Helfert at the State Institute for Folk Song}

\author{
Jarmila Procházková / prochazkova@imus.cas.cz \\ Kabinet hudební historie, Etnologický ústav AV ČR, v.v.i., Praha, CZ
}

\begin{abstract}
Vladimír Helfert's publishing activity in the field of musical folkloristics and ethnomusicology was not extensive. This study encompasses his work and organizational activities on the Moravian-Silesian Committee of the State Institute for Folk Song from 1924 to 1939.

His timeless approach to this subject matter was given by his depth of knowledge and feeling for musical aesthetics and by the dynamic understanding of the folk song that he carried over from Otakar Hostinský. This was also the source of his long-term interest in the situation in the field and the records involving all song genres. Helfert brought a critical approach towards sources and a feel for their systematic, scholarly treatment to his work at the State Institute for Folk Song. Interestingly, he took the first steps in this direction together with Leoš Janáček, and this may also explain the fundamental transformation of his opinions in evaluating Janáček as an artistic phenomenon. Helfert brought a number of talented students from the Musicology Seminar at Masaryk University into the study of folkloristics, and many of them later distinguished themselves as important scholarly authorities in this field of research.
\end{abstract}

\section{Key words}

Vladimír Helfert, Leoš Janáček, folklore studies, Státní ústav pro lidovou píseň (State Institute for Folk Song), Moravian folk song, methodology, folkloristics, politics in music 
Odkaz Vladimíra Helferta představuje pro minulé i stávající generace hudebních vědců stálý zdroj podnětů a badatel sám je příkladem mimořádné osobnosti, která zásadním způsobem formovala a dodnes nepřímo ovlivňuje hudebněvědný diskurs. Zůstává nesporným faktem, že tento vědec zanechal nejvýraznější stopu v oblasti hudební historiografie, na jejíž platformě se v různé intenzitě dotkl období 18. až 20. století. Ve srovnání s těmito tématy se jeho zájem o hudební folklor jeví a vždy bude jevit jako sekundární záležitost a indicie v tomto ohledu nenajdeme ani v jeho tvưrčím testamentu Moje literární plány.

Helfertova publikační činnost na poli hudební folkloristiky a etnomuzikologie není rozsáhlá a je zastoupená zejména statí $K$ otázce našeho hudebního folkloru. ${ }^{1}$ Fundované vyhodnocení tohoto textu nabídla studie Dušana Holého Metodologický přinos Vladimíra Helferta pro studium hudebniho folkloru z roku 1986, v níž nacházíme nadčasovou analýzu vědcových názorů v této oblasti. ${ }^{2}$ Holý ve zmíněném textu definuje tři hlavní problémové okruhy, tak jak jsou obsaženy v Helfertově stati: studium pramenů, psychologie a estetika lidové hudby a srovnávací studium lidové hudby. Studie Holého také upozornila na historický kontext Helfertovy recenze na Bartókovu stat' Mad'arská (Naše) lidová hudba a hudba sousednich národ ${ }^{3}{ }^{3}$ a dále připomíná badatelova teoretická a estetická východiska, která navazovala na Hostinského práce o lidové písni.

Vladimír Helfert kladl odborné otázky, které nastolovaly společné úvahy o hudbě lidové a artificiální. ${ }^{4}$ Připomeňme kontroverzní přednášku O lidovém muzikanství z roku 1913, poplatnou tehdejší autorově pozici v bojích o Dvořáka, která vyvolala vlnu kritiky. ${ }^{5}$ Do jiné roviny nás uvádí jeho studie z roku 1922 o původu nápěvu Marseillaisy, kde vstoupil na méně probádané pole mezi muzikologií a hudební folkloristikou. ${ }^{6}$ Využíval

1 HELFERT, Vladimír. K otázce našeho hudebního folkloru. Morava, měsíčník pro život sociálni, vědecký a umělecký, 1925, roč. 1, s. 230-236.

2 HOLÝ, Dušan. Metodologický přínos Vladimíra Helferta pro studium hudebního folkloru. In Vladimír Helfert v českém a evropském kontextu, R. Pečman (ed.) Brno: Svaz českých skladatelů a koncertních umělců, 1987, s. 31-34.

3 V češtině se vždy používal překlad s př́ilastkem „Mad’arská“, přesný překlad zní „Naše“. Srov. V. H. [HELFERT, Vladimír]. Poměrem mad’arské lidové písně k slovenské se zabývá Béla Bartók“ [...], Časopis Matice moravské, 1937, roč. 61, s. 455-457. Helfert reflektoval francouzské znění studie BARTÓK, Béla. La musique populaire des Hongrois et des peuples voisins, Archivum Europae Centro-Orientalis, 1936, roč. 2, č. 3-4, s. 197-232. (Helfert chybně cituje název časopisu). K politickému kontextu viz PROCHÁZKOVÁ, Jarmila. Bartók's Attempt at Cooperation with the State Institute for Folk Song in Czechoslovakia and Its Political Connotations. Hudebni věda, 2016, roč. 52, č. 1, s. 73-90.

4 Na tento rys upozornil R. Pečman. Srov. PEČMAN, Rudolf. Vladimír Helfert. Brno: Nadace Universitas Masarykiana, Edice Osobnosti, 2003; kapitola Doteky s hudebnim folklorem a folkloristikou, s. 116-119.

5 Přednáška byla pronesena ve Vědeckém klubu v Brně dne 28. března 1913. Rukopis přednášky je uložen v Moravském zemském muzeu v Brně, Oddělení dějin hudby (dále MZM-ODH), pozůstalost V. Helferta, sign. S 41. Přednáška vzbudila nesouhlas a diskusi na stránkách Moravských Listů, Hudební revue a čsp. Smetana. Viz POLEDŇÁK, Ivan. Soupis prací Vladimíra Helferta. In Musikologie sv. 5, Praha 1958, s. 253-313. Srov. záznamy č. 133, 135 a 137.

6 HELFERT, Vladimír. Contributo alla storia della „Marseillaise“. Rivista musicale italiana. Torino: Bocca; 1922, s. 622-638. Helfert polemizoval o charakteru a vzniku nápěvu. Julien Tiersot jeho vznik připisoval lidovému zpěvákovi a skladateli Rouget de Lisle, současně s akcentováním sociálního aspektu. Helfert naprotitomu poukazuje na příbuznost s kompozicí Marcie teatrali pro orchestr z roku 1790 ze strážnické magnisovské sbírky, existující před údajným vznikem nápěvu. 
přitom odkazy na Otakara Hostinského (36 nápěvů světských pisni českého lidu z XVI. stoletî) i poznatky z Nejedlého monografie o husitském zpěvu (Dějiny husitského zpěvu, 6 knih). Poukázal na charakter sbírek v zámeckých archivech v Čechách a na Moravě (zejména v Jaroměřicích nad Rokytnou), zaobíral se otázkami možného vzájemného vlivu konkrétních tvưrčích okruhů a argumentoval také polygenetickým principem, v muzikologickém prostředí spíše reflektovaným pod pojmem „loci communes“.

Ze všech těchto charakteristik je zřejmé, že Vladimír Helfert byl jedním ze vzácných badateli̊, kteří si udrželi otevřenost v náhledu na předmět studia a nepodlehli zdánlivé jistotě úzce definovaných zaměření. V podobném smyslu působil i na své žáky, což potvrzuje vzpomínka Roberta Smetany:

\begin{abstract}
„Diky V. Helfertovi jsem se nestal folkloristou, nýbrž studoval lidový zpěv jako muzikolog, tj. byl jsem schopen vidět lidovou piseň z pozic symfonie stejně jako naopak symfonii z pozic lidového zpě̀u, a naučil jsem se chápat hudbu komplexně jako homogenni a vnitřně kontinuálni jev, ve kterém každý projev, lhostejno zda lidová píseñ anebo symfonie, je si navzájem rovnýv tom, že je apriorně (krom talentem) podminèn jak užitými hudbotvornými prostředky, tak specifickým ideovým podnětem a nábojem, a to se všemi důsledky této formule pro pojeti a hlavně zkoumáni hudby jako jedné z řádných složek každého jednotlivého lidského života $i$ života lidských pospolitosti. “7
\end{abstract}

O komplexnosti jako o základním atributu Helfertovy práce se znalostmi a zjištěními, hovoří Roberta Smetana i ve stati z roku 1936, která byla publikovaná ve zvláštním čísle časopisu Index věnovaném vědcovým 50. narozeninám. ${ }^{8}$ Náš příspěvek si klade za cíl doplnit dosud neznámou faktografii odhalující Helfertův zájem o lidovou píseň a hudbu, zájem, který se projevil nejen zmíněným pedagogickým působením, ale také zcela konkrétními aktivitami ve Státním ústavu pro lidovou píseň (dále jako SÚLP) ${ }^{9}$

\title{
1. Jmenování a angažmá v SÚLP
}

Státní ústav pro lidovou píseň vznikl jako nástupnická organizace podniku Lidová píseň v Rakousku. Na podzim roku 1919 byli jmenováni jeho staronoví fukcionáři: pro Hlavní výbor (často též jako Ústřední výbor) předseda Jiří Polívka a jednatel Jiří Horák, předseda Českého výboru Zdeněk Nejedlý, předseda Moravské-slezského výboru (dále MSV) Leoš Janáček, předseda Německého výboru Gustav Jungbauer a předseda Slovenského výboru Milan Lichard. ${ }^{10}$

7 SMETANA, Robert. Za Vladimírem Helfertem. In Vladimír Helfert: pokrokový vědec a člověk. Studie, korespondence a vzpominky. Zvláštni přiloha Sborniku praci filosofické fakulty brněnské univerzity, H 9, Brno 1975, s. 63-67, zde s. 66 .

8 SMETANA, Robert. V práci pro lidovou píseň. Index, 1936, roč. 8, č. 3, s. 30-32.

9 Srov. heslo Vladimír Helfert v Českém hudebním slovníku osob a institucí, kde není zmíněno Helfertovo působení v SÚLP [on line] http://www.ceskyhudebnislovnik.cz/slovnik/index.php?option=com_mdictionary\&action=record_detail\&id=3343 [dat. 30. června 2016].

10 Poznatky k činnosti ústavu a jeho výborů čerpáme z fondu „Státní ústav pro lidovou píseň“ uloženém 
Z hlediska kontinuity celé instituce je zajímavá otázka, nakolik byl Helfert angažován v její činnosti před svým příchodem do Brna. Z materiálů se nepřímo dovídáme, že byl jmenován členem Českého výboru ještě před rokem 1918 (do roku 1918 pro podnik Lidová píseň v Rakousku, od roku 1919 pro SÚLP). ${ }^{11}$ Díky retrospektivním pramenům můžeme získat představu, při jaké př́ležitosti vědec s ústavem spolupracoval ještě za Rakouska-Uherska. Zdrojem této informace je protokol ze schůze Hlavního výboru SÚLP konané 30. dubna 1938 v Praze, kde byly vzpomenuty Nejedlého šedesátiny. Jiří Horák pronesl oslavnou řeč, jejíž obsah byl zčásti přenesen do protokolu: „Jednatel vzpomněl dále velikých zásluh, které si ziskal prof. Nejedlý v době nejtěžši persekuce v r. 1917, kdy bývalá rakouská vláda žádala, aby se všechny sbirky české zaslaly do Vídně. Tehdy prof. Nejedlý svou rozhodnosti i rozvahou zachránil sbirky a kromě toho spolu s prof. drem Helfertem provedl rozsáhlou dưvěrnou akci mezi obětavým vlasteneckým studentstvem s takovým úspěchem, že byly zdarma pořizeny opisy všech sbírek pro př́pad, že by český výbor byl býval nucen ustoupiti násili a sbírky prece jen vydati do Vidně." Stručná poznámka poukazující k těmto dosud neznámým skutečnostem zazněla již o rok dříve, když Z. Nejedlý na schůzi dne 30. dubna 1937 informoval o ministerském jmenování V. Helferta do funkce předsedy MSV (ze dne 28. ledna 1937) a při této příležitosti připomněl jeho „zásluhy za války“. ${ }^{12}$ Není pochyb o tom, že Janáček znal Helferta z této stránky, jelikož v dané době společně s Nejedlým úspěšně koordinovali postup vůči rakouským úřadům. ${ }^{13}$ Informace tohoto typu se v inkriminované době obvykle nezapisovaly do oficiální dokumentace, i proto byly tyto skutečnosti dosud zcela neznámé.

V souvislosti s Helfertovým přestěhováním z Prahy do Brna jednal Hlavní výbor SÚLP také o jeho přestupu z Českého do Moravsko-slezského výboru. ${ }^{14}$ Po schůzi konané 5. ledna 1924 byl zaslán podnět na Ministerstvo školství a národní osvěty, které se zpět dotázalo, zda je s tímto návrhem srozuměn MSV. Byl to důvod, proč psal předseda Hlavního výboru Jiří Polívka zvláštní dopis adresovaný Janáčkovi, v němž byl ministerský dotaz přeposlán na brněnskou pobočku. ${ }^{15}$ Janáček svolal na 14 . května 1924 schůzi MSV, kde byla záležitost přestupu Helferta oficiálně projednána a schválena i s odkazem

v Masarykově ústavu - Archivu Akademie věd (dále MÚ-AAV), dále z dokumentace SÚLP uložené ve sbírkách Etnologického ústavu AV ČR, pracoviště Brno (dále EÚB) a ze sbírek Oddělení dějin hudby Moravského zemského muzea v Brně (dále MZM-ODH). Historie SÚLP je předmětem dlouhodobé badatelské pozornosti autorky této studie a měla by být shrnuta v samostatné publikaci.

11 MÚ-AAV, fond SÚLP, kart. 1, inv. č. 4. Všechny dále citované zápisy (protokoly) ze schůzí Hlavního výboru jsou uloženy v této jednotce a jsou řazeny chronologicky. Dokumentace k činnosti Českého výboru je torzovitá, v budoucnu není vyloučeno možné doplnění, např. z dosud nepřístupné části fondu Z. Nejedlého (taktéž v MÚ-AAV).

12 Protokoly ze schůzí Hlavního výboru konaných 30. dubna 1937 a 30. dubna 1938.

13 Text Janáčkova stanoviska byl otištěn, viz HRABALOVÁ, Olga. K dějinám hudebněfolkloristického bádání na Moravě. Národopisné aktuality, 1982, roč. 19, č. 3, s. 169-178, s. 176-177.

14 Zápis ze schůze Hlavního výboru konané 5. ledna 1924 přímo o Helfertovi nehovoří, s největší pravděpodobností se jednalo o tehdy čtenou zprávu Českého výboru za rok 1923. O urgenci dané záležitosti se zmiňuje „Zpráva jednatelova za r. 1925“. MÚ-AAV, fond SÚLP, kart. 1, inv. č. 4.

15 Polívkův dopis adresovaný Janáčkovi, dat. v Praze 2. května 1924, odkazuje na přípis z Ministerstva školství a národní osvěty, dat. 29. března 1924. EÚB, sign. X7, fond SÚLP, složka Organizace I., rok 1924. 
na údajné dřívější jednání v roce 1923. Poté Janáček ve své odpovědi Hlavnímu výboru vyjádřil souhlas s Helfertovým angažmá v Brně (př́iloha 1): ${ }^{16}$

„P. T. Hlavnimu výboru státního ústavu pro lidovou piseň!

Mor. slezský výbor sděluje na dotaz ze dne 2. května 1924, že souhlasí, aby prof. Dr. Vladimír Helfert byl členem mor. slez. odboru (misto členem českého odboru). Dr. Vl. Helfert s tímto přemistěnim souhlasí.

Brno 15. května 1924

\section{Leoš Janáček"}

Oficiální jmenování z Ministerstva dlouho nepřicházelo, a tak ve zprávě MSV z 24. července 1925 se znovu zdůrazňuje, že výbor trvá na přeložení Helferta do Brna. ${ }^{17}$ Nominace byla urgována ještě v lednu 1926, kdy na schůzi Hlavního výboru 8. ledna 1926 Nejedlý navrhl, že není třeba déle čekat.

„Prof. Souček dále žádá, aby bylo urgováno jmenováni dra Helferta členem výboru moravského. Jednatel čte koncept př́pisu poslaného své doby Mšano. Prof. Nejedlý navrhuje: Dr. Helfert byl již za vlády rakouské jmenován členem výboru českého. Neni tedy třeba, aby bylo zvláště žádáno potvrzeni min., je-li dr. H. nyni ve výboru moravském. Stači, když hlavni výbor prohlásí výboru moravskému, že souhlasí, aby dr. Helfert pưsobici nyni v Brně, byl členem výboru moravského. Souček s tím souhlasí. Postup navrhovaný Nejedlým byl pak v zásadě schválen jako normativní i v jiných př́padech obdobných."

Helfert se poprvé zúčastnil schůze MSV 26. listopadu 1926, avšak ani jeden z projednávaných bodů se jej př́ímo netýkal. ${ }^{18}$ Konkrétní úkol mu byl přidělen na následující schůzi 24. března 1927. Janáček tehdy předpokládal rychlé vytištění Moravských písni milostných a plánoval následující svazek. Titul měl být věnovaný „taneční písni“ a realizace měla být svěřena Vladimíru Helfertovi. ${ }^{19}$ Ten se však z příští schůze na poslední chvíli omluvil s poukazem na povinnosti v Semináři pro hudební vědu Masarykovy university (4. května 1927). Situace se doslova opakovala 20. prosince 1927, kdy byl Helfert opět omluven, ačkoliv měl Janáček v plánu hovořit v souvislosti s ním o taneční písni. ${ }^{20}$ Poměrně spolehlivě lze vydedukovat, že Janáčkovy plány se v tomto ohledu nesetkaly s aktuálními zájmy Helferta, který zůstával stranou dění a ani se v této době neúčastnil schůzí

16 MÚ-AAV, fond SÚLP, kart. 28, inv. č. 476, Janáčkův rukopis.

17 MÚ-AAV, fond SÚLP, kart. 29, inv. č. 502, Zpráva odboru moravsko-slezského vědeckého ústavu pro lidovou píseň, Janáčkův rukopis dat. Brno 24. července 1925. Bod 6.) Výbor truá na tom, aby Dr. Vlad. Helfert byl členem výboru mor-slezského.

18 EÚB, sign. X7, fond SÚLP, složka Organizace I., rok 1926. Na zápisu ze schůze se postupně podíleli L. Janáček, S. Souček i V. Helfert.

19 Na volbu tématu pro Helferta mohlo mít vliv povědomí rozšířené v odborných kruzích o studii, kterou psal jeho děd jako spoluautor. Viz HELFERT, Josef Alexander - HOSTINSKÝ, Otakar. Volkslied und Tanz der Slaven. In Die Oesterreichisch-ungarische Monarchie in Wort und Bild: Böhmen (1. Abtheilung). Wien: Verlag der kaiserisch-königlichen Hof- und Staatsdruckerei, 1894, s. 462-482. Srov. HOLÝ, op. cit., s. 31.

20 EÚB, sign. X7, fond SÚLP, složka Organizace I., rok 1927. Zápis ze schůze 4. května 1927 obahuje bod 4: „Tanečni píseñ obstará prof. dr. Helfert.“ Tamtéž uloženy materiály ke schůzi 20. prosince 1927, které obsahují Janáčkův náčrt programu s bodem „V. Taneční písně naše“; v zápisu z této schůze se bod neobjevil. 
Hlavního výboru v Praze. ${ }^{21}$ Vedle nedostatku času a důvodů organizačních zde jistě hrály roli i rozdílné názory na to, jakým zpo̊sobem se má MSV, potažmo celý Ústav profilovat. Helfert nebyl př́itelem prezentace folkloru ve stylizované dramaturgii a měl svou vlastní a odlišnou představu o smyslu folkloristické práce. Například slavné vystoupení myjavských hudců na Mezinárodním hudebním festivalu ve Frankfurtu nad Mohanem v květnu 1927, které organizoval Janáček a jako o úspěchu o něm referoval i na zmíněné schůzi MSV 20. prosince 1927, komentoval Helfert v dopise Stanislavu Součkovi velmi kriticky: „Mám vždy z toho okázalého vystavování lidového uměni živého - at’ už je lidové nebo nelidové - dojem, že si jen škodíme. [...] Cizina pak na nás pohližz jen jako na exotický národ a nic víc. Proti tomu bude dobř postavit skutečnou kulturu - tedy vědu." 22

Přestože o vědeckosti Ústavu Janáček také velmi často hovořil, vzhledem k jeho osobnímu naturelu převládalo zaujetí folklorním materiálem, dosti vzdálené vědecké systematice. Na začátku roku 1928 se blížilo zahájení Výstavy soudobé kultury v Brně, což Janáčka i celý MSV přimělo k intenzivním přípravám. Od února do června se každý měsíc odbývalo pracovní setkání. Helfert se účastnil únorového sezení (2. února 1928), 9. března dostal za úkol připravit pro výstavu fotografie, ${ }^{23} 4$. dubna S. Souček doporučil, aby Seminář pro hudební vědu pod vedením Helferta spolupracoval na vytvoření mapy sebraných písní. Tato mapa byla připomínána Janáčkem na schůzi také 13. června 1928. Obecně lze dodat, že Helfert sám se v tomto období neprofiloval jako reprezentant této badatelské oblasti a zřejmě tak nebyl vnímán také okolím. Jak je patrné z korespondence, Jiří Horák tak mohl jen litovat, že Helfert nebyl pozván na I. mezinárodní kongres pro lidové umění, který se konal 7.-13. ř́jjna 1928 v Praze..24

Po smrti Janáčka 12. srpna 1928 nastaly v MSV výrazné personální posuny. Jiří Horák doporučil úředním i osobním dopisem Stanislavu Součkovi, aby se chopil ř́izení MSV. Na schůzi 1. října 1928 Helfert navrhl do funkce předsedy MSV právě Součka a Hlavní výbor tento krok schválil 20. prosince 1928. Jako místopředseda byl jednomyslně navržen V. Helfert, kterého doporučoval i J. Horák s ohledem na to, že bude v Hlavním výboru jako delegát brněnské pobočky reprezentovat odborníka na hudební stránku. ${ }^{25}$ Souček svému zástupci výjimečně svěřoval vedení schůzí a většinou společně jezdili na schůze do metropole. ${ }^{26}$ Jejich korespondence prozrazuje sympatický osobní vztah. Například

21 V letech 1926-1928 byli jako zástupci MSV na schůzích Hlavního výboru v Praze 8. ledna 1926, 25. dubna 1927 a 7. ledna 1928 vždy L. Janáček, S. Souček a P. Váša.

22 Moravský zemský archiv, fond G 65, kart. 2. Citováno podle PAVLICOVÁ, Martina. Z historie Státního ústavu pro lidovou píseň v Brně v meziválečném období. In Od Pracovního výboru pro českou národni píseñ na Moravě a ve Slezsku k Ústavu pro etnografii a folkloristiku 1905-1995, L. Uhlíková (ed.) Brno: Akademie věd České republiky, 1995, s. 24-29, zde s. 25.

23 Fotografie pořizoval Státní památkový úřad pro Moravu a Slezsko, viz přípis z 14. června 1928. EÚB, sign. X7, fond SÚLP, složka Organizace I., rok 1928.

24 MZM-ODH, pozůstalost V. Helferta, sign. D 396, dopis J. Horáka adresovaný V. Helfertovi, datovaný 17. listopadu 1928 („Kol. Zich [Otakar Zich] mi řikal, že prý jste nebyl pozván.“)

25 MZM-ODH, pozůstalost V. Helferta, korespondenční lístek S. Součka V. Helfertovi sign. A 1815; schůze MSV 20. prosince 1928 v Brně.

26 Na schůzích Hlavního výboru v Praze se za MSV účastnili: 9. ledna 1929 a 8. ledna 1930 Souček, Helfert, Váša; 10. ledna 1931 a 9. ledna 1932 Souček, Gregor, Helfert; 2. února 1933 Souček, Gregor (Helfert omlu- 
v lednu 1932, když Helfert onemocněl trombózou, dostával od Součka dobře míněné rady. Doporučení znělo ve smyslu, že nejlepší službu udělá nyní Helfert svému oboru tím, když bude dbát na své zdraví. ${ }^{27}$ Měsíc po Janáčkově smrti, 14. září 1928 Souček a Helfert přestěhovali sbírky MSV z Varhanické školy na děkanát Filosofické fakulty a řešili řadu záležitostí do té doby přehlížených. Na adresy dřivějších spolupracovníků $\mathrm{s}$ úspěchem rozeslali výzvu k vyplnění formuláře Reverzu, čímž se jim podařilo definitivně zajistit vlastnická práva Ústavu k získaným sbírkám. ${ }^{28}$ Společně s Karlem Vetterlem se věnovali roztřídění materiálů z Janáčkovy pozůstalosti, tak aby se všechny materiály související se skladatelovou folkloristickou činností dostaly do sbírek SÚLP. ${ }^{29}$

Stanislav Souček zemřel 30. prosince 1935. Během schůze MSV 27. ledna 1936 byl Helfert nominován a jednomyslně zvolen na uprázdněné místo předsedy MSV, Františka Kyselková byla současně jmenována místopředsedkyní. ${ }^{30}$ Oba tyto návrhy, které přednesl Pavel Váša, byly následně schváleny v Praze. ${ }^{31}$ Ve vedení MSV Helfert setrval až do svého zatčení dne 14. listopadu 1939. V SÚLP řešil a rozvíjel řadu projekti̊, jak těch zahájených před jeho nastoupením do vedoucích funkcí, tak také těch, které sám inicioval, a tudíž ideově formoval.

\section{Moravské písně milostné (MPM)}

Helfertova činnost v rámci SÚLP se odvíjela v rovině úřední, stejně jako v záležitostech výhradně odborných. Navenek se jeho působení projevilo pracovním podílem na přípravě hudební stránky Moravských pisni milostných, edice, na jejímž titulním listě nacházíme pouze jména Leoše Janáčka a Pavla Váši. ${ }^{32}$ Záhy po umělcově smrti nastala potřeba tuto publikaci dokončit. Již v září 1928 jednatel Horák vyslovil doporučení, aby se Helfert

ven); 3. března 1934 Souček (Gregor a Helfert omluveni); 2. března 1935 Gregor, Souček (Helfert omluven); 28. března 1936, 30. dubna 1937 a 30. dubna 1938 Gregor, Helfert; 8. června 1940 Gregor.

27 MZM-ODH, pozůstalost V. Helferta, dopis S. Součka V. Helfertovi, dat. 12. ledna 1932, sign. B 737.

28 PAVLICOVÁ, op. cit., s. 25.

29 EÚB, sign. X7, fond SÚLP, složka Organizace I., rok 1928, Výroční zpráva za rok 1928.

30 Helfert obdržel svůj jmenovací dekret v dopise od jednatele J. Horáka dne 3. dubna 1937, současně se jmenováním prof. dr. Tomáše Čepa řádným členem MSV. Helfert si na Horákův dopis dopsal poznámku: (dekret z 20. I. 37, č. 163.369/36-V/2) náurh ze 16. IV. 36.

31 EÚB, sign. X4/198, zápis ze schůze MSV dat. 27. ledna 1936, rukopis A. Gregora podepsaný předsedou. Helfert tehdy mj. přečetl přípis z Ministerstva (dat. 10. ledna 1936), jímž bylo vysloveno čestné uznání člence MSV F. Kyselkové. Ve stejném smyslu srov. protokol ze schůze Hlavního výboru 28. března 1936 v Praze.

32 JANÁČEK, Leoš - VÁŠA, Pavel. Moravské písně milostné. I. Praha: SÚLP, Orbis, 1930-1936 [1937]. Edice vycházela od roku 1930 v šesti sešitech. V podobě knižní byla svázána s patitulem a titulní stranou prvního sešitu, vyšla v roce 1937 s datem 1930. Helfertovo jméno se objevuje na s. 474 v podtitulu Seznamu zpěváků a na straně 491 v podtitulu Rejstříku nápěvů. Sešitové exempláře mají navíc jednotně potištěné strany impressum s textem: LIDOVÁ PÍSEŇ / V REPUBLICE ČESKOSLOVENSKÉ / VYDÁVÁ STÁTNÍ ÚSTAV PRO LIDOVOU PÍSEŇ V ČSR. / ŘADA A / PÍSNĚ ČESKÉ A MORAVSKÉ / DÍL V. / MORAVSKÉ PÍSNĚ LYRICKÉ / SVAZEK I. / PÍSNĚ MILOSTNÉ./ I. PRAHA 1930 / NÁKLADEM STÁTNÍHO ÚSTAVU PRO LIDOVOU PÍSEŇ V ČSR. / TISKEM GRAFIE V PRAZE. Obálka se mírně odchyluje. 
v této věci ihned obrátil na Nejedlého. ${ }^{33}$ Pavel Váša pokračoval v př́ípravě písňových textů. V té době již byly na edici vyhotoveny posudky S. Součka a Z. Nejedlého, ale ani kritika druhého jmenovaného, ani jeho blízké kontakty s hudebním editorem, neměly ovlivnit změnu obsahu.$^{34}$ Stalo se tak zřejmě i díky obežretnosti ústavních funkcionářů, jak o tom svědčí dopis Jiř́ího Horáka adresovaný Helfertovi 17. listopadu 1928:

„Doufám, že jste se již ujal práce o díle Janáčkově a prosím Vás o bližši zprávy v tom smèru. Myslim, že spolu souhlasíme, pokud jde o zpi̊sob Vaši práce. V tekstu Janáčkově se ovšem již nic nemůže mèniti, jde tedy jen o to, abyste se staral o hudebni stránku (korektury a tisk). Snad jste se v té věci dohodl s prof. Nejedlým?"“35

Helfert byl v tomto smyslu pod dohledem i v brněnském prostředí, o čemž svědčí Součkova zpráva o činnosti MSV za rok 1929, která připomněla sedm vytištěných archů

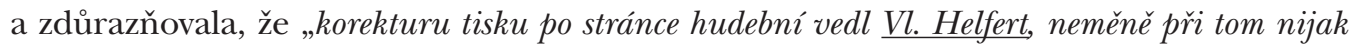
Janáckovy úpravy“. ${ }^{36}$

Helfert odevzdal písně do sazby v roce 1933. Teprve 3. března 1934 Nejedlý navrhl, aby Janáčkovu sbírku uzavíral rejstř́ík. Původně nebyl plánován, jelikož svazek byl vnímán jako první díl pokračující řady. ${ }^{37}$ Sešity vycházely průběžně: 1 . a 2 . sešit v roce 1930 , 3. sešit 1931, 4. sešit 1932, 5 . sešit 1933, 6. sešit $1936,3^{38} \mathrm{v}$ roce 1937 tak byl dokončen tisk a sešity byly svázány do jedné publikace s titulním listem prvního sešitu, tedy s datem 1930 . Celé toto období je ve znamení urgencí zasílaných na adresu tiskárny. Helfert v závěru doplnil rejstř́iky zpěváků a zejména katalog nápěvů, který ve své době znamenal první systematické řešení daného úkolu. Odborná kritéria, kterými byly nápěvy tříděny, měly svůj metodologický limit a zástupci prřšstí badatelské generace (Karel Vetterl a Jaromír Gelnar) tato omezení přesvědčivě pojmenovali a současně navrhli komplexnějš́ ŕ řešení. ${ }^{39}$

Zajímavé bylo též jednání o atribuci. Otázku otevřel Jiří Polívka na schůzi Hlavního výboru 8. ledna 1930. Helfert sám navrhl postup, že „,na konci tisku bude poznámka o jeho spolupráici“. O dva roky později se na stejné platformě řešila otázka honorářủ. Souček tehdy referoval o rozdělení honoráře za uvedenou edici:

„Po zesnulém dru. L. Janáckovi se ujal vedeni hudebni stránky edice prof. dr. Vlad. Helfert, který také provádi korekturu. [...] Za 1 tiskový arch publikace byl své doby ustanoven celkový

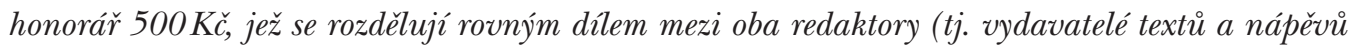
dostanou každý po $250 \mathrm{Kč}$ ). Dru. Helfertovi budiž vyplacena polovice honoráre, který by byl prípadl dru. L. Janáckovi t. j. 125 Kč za tiskový arch čili 11/4 honoráře celkového. Tedy za 4 sešity

33 Dopis Horáka adresovaný S. Součkovi, dat. 20. září 1928. EÚB, sign. X7, fond SÚLP, složka Organizace I., rok 1928.

34 Na schůzi Hlavního výboru SÚLP, která se konala 4. listopadu 1929, bylo všemi hlasy rozhodnuto, že sbírka Moravské pisně milostné nebude tištěna ve fonetickém přepisu.

35 MZM-ODH, pozůstalost V. Helferta, sign. D 396, dopis J. Horáka datovaný 17. listopadu 1928.

36 MÚ-AAV, fond SÚLP, kart. 29, inv. č. 502, výroční zpráva MSV za r. 1929.

37 Imprimatur rejstř́iků Helfert podepisoval v srpnu 1935.

38 Časová proluka mezi 5. a 6. sešitem byla způsobena nedostatkem finančních prostředků v době hospodářské krize.

39 VETTERL, Karel - GELNAR, Jaromír. Nad katalogy písňových nápěvů. Český lid, 1962, roč. 49, s. 241-249. Srov. též HOLÝ, op. cit., s. 32-33. 
po 6 tisk. arších dostane prof. Helfert úhrnem (125 x 24) 3000 Kč. Zbytek honorář Janáčkova pripadne pozuistalosti.“

Na téže schůzi Hlavního výboru v Praze 9. ledna 1932 také zazněl poučený dotaz Dobroslava Orla na rozsáhlou Janáčkovu předmluvu, o které věděl díku Aloisi Kolískovi. Helfert tehdy odpovídal, že může být v pozůstalosti a že o ní MSV nic neví. Souček pragmaticky navrhl, aby bylo do protokolu napsáno, že se žádná předmluva neztratila. Nemáme další indicie o tom, že by ji někdo v Janáčkově pozůstalosti hledal v souvislosti s vydáním MPM, ostatně sbírky byly nezkatalogizované a trvalo další desetiletí, než byly Janáčkovy rukopisy identifikovány. Část z Janáčkovy plánované pětidílné předmluvy k Morauským písním milostným otiskl Jiří Vysloužil v edici Leoš Janáček - O lidové pisni a hudbě: dokumenty a studie. ${ }^{40}$

\section{Zájem o ústavní sbírky a jejich odborné zpracování}

Díky zvolenému tématu máme možnost sledovat Vladimíra Helferta při aktivitách, které byly při charakterizování jeho vědeckého typu dosud neznámé. Máme zde na mysli jeho studium, zpracování a odborné posuzovaní sbírek SÚLP, o jejichž získávání instituce usilovala kontinuálně i ve dvacátých a třicátých letech 20. století. Podle finančních možností se postupně odkupovaly od sběratelů výsledky jejich práce a MSV tak činil na základě odborných posudků, které zadával respektovaným odborníkům. I na tomto poli lze spatřovat Helfertovu uvážlivost. Odmítl vypracovat doporučení na písňovou sbírku Antonína Novotného (1858-1947), když neměl možnost seznámit se s jejím obsahem. Naopak velmi pozitivně kvitoval práci sběratele Bohuslava Indry (1891-1961), jehož obsáhlý konvolut byl vzápětí do ústavu zakoupen. ${ }^{41}$

Bezprostředně po svém nástupu do funkce předsedy MSV Helfert rozhodl uspořádat nový plošný nábor sběratelů. Vědcovo zaujetí je patrné i z rukopisných konceptů dopisů, jimiž byly osloveny školní inspektoráty, muzejní organizace a kulturní zařízení. Akci sumarizoval Helfert na schůzi MSV 16. března 1937: ústav oslovil padesát okresních školních inspektorátů a všechna krajinská (regionální) muzea v Zemi Moravskoslezské. Přípis žádal o upozornění na osoby vhodné pro spolupráci při sbírání lidových písní a hudby, dotazoval se na existenci rukopisných i tištěných sbírek v terénu i v muzejních sbírkách, či zda v kraji žijí zpěváci vhodní pro zachycení na „gramofonové desky“. Výsledkem této akce byl masivní nárůst informátorů, jejichž údaje byly zaneseny do zvláštní kartotéky nových spolupracovníků. Jednalo se o 96 nových sběratelů ze 75 míst. Jejich dopisy přicházely v únoru a březnu 1937 také na základě výzvy v denním tisku (České slovo aj.). Helfertovy rukopisné soupisy budoucích spolupracovníků čítají tři fólia formátu B5,

40 Srov. Jiří Vysloužil v edici Leoš Janáček, O lidové písni a lidové hudbě: dokumenty a studie (Praha: Státní nakladatelství krásné literatury, hudby a umění, 1955, s. 503-509, 442-445, 622-624). V kompletní podobě a pořadí se Janáčkova předmluva připravuje k otištění ve druhém dílu Janáčkova Folkloristického díla, řada I, sv. 3-2 (Editio Janáček Brno), kde budou vyhodnoceny a uveřejněny starší verze.

41 EÚB, sign. X7, fond SÚLP, složka Organizace I., rok 1930, zápis ze schůze 20. listopadu 1930, rukopis K. Vetterla. 
poté předal agendu Aloisu Gregorovi, který dopsal další desítky potencionálních spolupracovníků. ${ }^{42}$ (Př́loha 2) V roce 1938 Helfert plánoval učinit jejich důkladnou kritiku a sběratelé, kteří by prošli tímto výběrem, měli obdržet přesně vypracované pokyny pro sbírání. Tyto plány však již badatel nestihl realizovat.

Díky archiváliím máme možnost doložit, že na rozsáhlý archiv písní měl zásadní vliv Helfertův zpo̊sob myšlení a kritický přístup k pramenům, který se začal do činnosti MSV prosazovat s jeho příchodem. Již na schůzi 18. dubna 1928 lze shledávat snahu o systematičtější třídění písní. V zápisu ze schůze (shodou okolností rukopis Helfertův) lze číst v bodě 3: „Bude pořizen listkový katalog všech pisní. Za tím účelem zjedná Helfert tři posluchače, kteři materiál rozepiší. Odměna bude nabidnuta: 5 Kč za hodinu. "43

Zpráva MSV za rok 1928 vykazuje úspěšné plnění tohoto úkolu a je unikátní v tom smyslu, že dokládá společné katalogizační úsilí Janáčka a Helferta:

„[...] Za to začal nový listový katalog, majici $i$ počátečni nápěvky; pořidili je pod dozorem Leoše Janáčka a Vladimíra Helferta 24. IV. až 26. VI. Frant. Kaizrlik, F. Kocman, J. Šereda a L. Šupitová; celkem zregistrováno tak 16.521 čísel.

Práce ta bude doplněna po roztř́dèni archivu čísly dosud nezkatalogizovanými. Nový tento katalog ukázal se nutným při př́pravách k Výstavě soudobé kultury. "

Helfert zůstal vůdčím duchem katalogizačních prací i v následujících letech, tedy i v době předsednictví S. Součka, jak o tom svědčí zápis ze schůze MSV konané 7. února 1930:

„[Předseda] upozorňuje, že pisňový materiál bude nutno přerovnati, kterýžto úkol vzal na sebe Dr. Helfert. Nové sbirky budou katalogizovány s označením II. na nově zakoupeném papire (podle vzorku). Práci budou prováděti posluchači z hudebně věd. semináře pod dohledem prof. Helferta (honorář 5 Kč na hodinu). Schváleno zakoupeni 400 archů papíru a honorování katalogizačni práce. Paralelněs katalogizací má se prováděti i opis písñového materiálu. Originály nemá editor užívati pro tiskárnu. Přijato jednohlasně. Předseda dává $k$ debatě $i$ otázku ziskáváni důvěrniků pro Ú.L.P. [SÚLP] a pořizeni rejstřiku sběrateli̊. [...] Usnešeno také propagovati činnost ÚLP rozhlasem ve formě přednášky s ukázkami. Vypracováni přednášky ujme se prof. Helfert." 45

O rok později, na schůzi 25. června 1931 jsou komentovány pokračující práce: „Dr. Helfert informuje výbor, jak pokračuje katalogizace. Větši sbirky jsou již hotovy. Jeden ze studentů bude pracovat i o prázdninách. " ${ }^{46} \mathrm{Na}$ korespondenčním listě z 3. ledna 1933 Helfert hlásí Aloisu Gregorovi, že bylo dokončeno opisování a katalogizační práce tak, „[...] že nyni zbývaji ke zpracováni pouze nové př́růstky, tím je dokončeno to, co nynější výbor po [smrti] Janáckově si předsevzal. " 47

42 EÚB, sign. X3/82.

43 EÚB, sign. X7, fond SÚLP, složka Organizace I., rok 1928.

$44 \mathrm{~K}$ uvedeným jménům je $\mathrm{v}$ archivu a knihovně MU jediná zmínka - Kaizrlíkova práce s názvem Lenaus epische Dichtungen, rukopis, $131 \mathrm{f}$.

45 EÚB, sign. X7, fond SÚLP, složka Organizace I., rok 1930, rukopis K. Vetterla.

46 EÚB, sign. X7, fond SÚLP, složka Organizace I., rok 1930, rukopis A. Gregora.

47 EÚB, sign. X4/193. 
Ve zprávě za rok 1934 se objevuje zmínka o čerpání dotace na proplacení katalogizačních prací, na nichž pracoval Jan Chlup. ${ }^{48}$ Současně byla zahájena katalogizace podle sběratelů, na které pracoval zejména Karel Vetterl a tuto činnost ukončil v roce 1935. Další posuny a specifikace katalogizačních parametrů jsou patrné pod Helfertovým vedením v roce 1936, jelikož Zpráva o činnosti za tento rok hlásí, „[...] že se nadále pracuje na pořizováni melodického katalogu nasbiraných pisni. Práce se děje za účasti vybraných posluchačů z hudebně vědeckého semináře při filos. fakultě Masarykovy univ." “49

Pedagog Helfert zde využíval možnost zapojit do práce studenty, kterým byla tato problematika blízká. Je pozoruhodné, jak uměl rozeznávat talenty a pro jejich angažování a zejména pro získání prostředků na jejich odměny vyvíjel nemalé úsilí. Společně se S. Součkem tak získali pracovníky, jejichž jména jsou dnes nejen symbolem trvalého odkazu hudební folkloristiky, ale obecného kulturního přínosu: Roberta Smetanu, Bedřicha Václavka a Karla Vetterla. Čeněk Gardavský byl takto zaměstnán jako pomocná vědecká síla na Filosofické fakultě a Helfert mu zařídil stipendium pro nezaměstatnou inteligenci.

Plně se tak potvrzují slova Jiřího Vysloužila, který do ústavu sice nastoupil až po 2. světové válce, nicméně byl svědkem pracovního elánu a erudice většiny výše zmíněných osobností. V bilančním článku o historii ústavu se vyjádřil, že „[...] prvni kroky $k$ zvědečtěni práce položil až prof. Vlad. Helfert, jehož podněty nyni důsledně provádi, doplňuje a rozviji od r. 1945 nově reorganizovaný výbor. "50

\section{Fonografická akce III. třídy České akademie věd a umění}

Vedle úředních úkolů a pravidelné péče o archiv V. Helfert zdědil po S. Součkovi spolupráci na fonografickém projektu, který organizovala III. (dialektologická) třída České akademie věd a umění. První etapa se uskutečnila 19. září až 1. listopadu 1929 ve spolupráci s francouzskou firmou Pathé. Akci vedl do své abdikace Josef Chlumský, o nahrávání lidových písní se zasloužili Otakar Zich, Karel Plicka, Josef Hutter a francouzskou stranu zastupoval Henry Barraud. ${ }^{51}$

Třebaže členové MSV pod Součkovým vedením zprostředkovali v Praze návštěvu zpěváků, organizátoři akce je k nahrávání údajně nepozvali. ${ }^{52}$ Brněnský výbor přesto

48 EÚB, sign. X, fond SÚLP, složka Organizace I., rok 1934/5, rukopis A. Gregora korigovaný S. Součkem. Jan Chlup (1889-1968) se později soustředil na speciální pedagogiku a publikoval řadu studií týkajících se péče o postižené děti.

49 MÚ-AAV, fond SÚLP, kart. 29, inv. č. 502, zpráva MSV za rok 1935 a 1936.

50 VYSLOUŽIL, Jiří. K organisaci hudebně lidopisného bádání na Moravě a ve Slezsku. In Musikologie sv. 2 , Praha - Brno - Bratislava: Svaz československých skladatelů, 1949, s. 214-220, zde s. 217-218.

51 KRATOCHVÍL, Matěj. Úvod. In Lidová hudba v Československu (Nahrávky Fonografické komise České akademie věd a umění) 1929-1937, ed. M. Kratochvíl. Praha: Etnologický ústav AV ČR, v.v.i., 2009, s. 22-42.

Zpráva CHLUMSKÝ, Josef. Fonografický a gramofonový archiv České akademie věd a umění. Časopis pro moderni filologii, 1930, roč. 16, s. 189-192.

52 Referát MSV na schůzi Hlavního výboru v Praze 8. ledna 1930, konané za účasti Součka, Váši a Helferta. 
neustával v aktivizování sítě zpěváků, kteří by připadali v úvahu pro př́šstí akce, a ještě v roce 1932 přicházely desítky návrhů přímo z terénu jako dozvuky akce v roce 1929.

O připravované druhé fázi nahrávání se Helfert dozvěděl nové podrobnosti na schůzi Hlavního výboru 28. března 1936 v Praze a navštívil tehdy J. Chlumského. Ten však 15. května 1936 oslovil ředitele konzervatoře v Brně Jana Kunce a žádal jej o doporučení vhodných osob na Moravě. ${ }^{53}$ Výbor MSV byl velmi zmaten a rozhořčen a doporučil Helfertovi, aby na tuto informaci reagoval dopisem J. Kuncovi.

Na schůzi 7. prosince 1936 pak Helfert svým kolegům v Brně zevrubně referoval o problematické komunikaci, která se na konto toho vyvinula s Fonografickou komisí ČAVU a jejímž důsledkem byl přesun termínu de facto o rok později. Ve zprávě za rok 1936 MSV sumarizoval četné aktivity a snahy, které se projevily zasláním jednašedesáti adres zpěváků. ${ }^{54}$ Nahrávky byly nakonec pořízeny v Praze 25. - 29. ř́íjna 1937 ve spolupráci s firmou Esta v režii Josefa Huttera, bez aktivní účasti členů MSV. Ti sami na sklonku roku 1937 žádali o sdělení jmen zpěváků, kteří se ve druhé etapě nahrávání zúčastnilii. ${ }^{55}$

\section{Edice českých zlidovělých písní}

Druhý velký projekt, jímž se Helfert z titulu své funkce zabýval a jehož zahájení se datuje do období před jeho nástupem do funkce předsedy MSV, byla edice Roberta Smetany a Bedřicha Václavka České světské pisně zlidovělé. ${ }^{56}$ Přípravné fáze byly podporovány průběžně od roku 1930 a v agendě SÚLP se po celou dobu objevují pobídky k dokončení rukopisu. Na schůzi ústředí se rozhodlo, že práci Václavkovu a Smetanovu prohlédnou v roce 1934 Helfert a Jan Jakubec, o dva roky později (28. března 1936) byl referát svěřen Franku Wollmannovi a Zdeňku Nejedlému. Na schůzi MSV 4. května 1936 dostal Helfert za úkol urgovat mladší kolegy, „[...] aby si s praci pospišili““.57

Realizátoři projektu měli k tehdejším autoritám SÚLP blízký vztah. Robert Smetana byl žákem Helfertovým, na edici pracoval s doporučením od Stanislava Součka; literární vědec B. Václavek prošel seminářem u Jana Jakubce. ${ }^{58}$ Všem třem jmenovaným pedagogům byl první svazek dedikován.

Vladimír Helfert se pak opakovaně snažil o jmenování Smetany a Václavka za členy MSV a vytvářel pro ně vhodné pracovní podmínky. ${ }^{59}$ Smetana se zajímal o členství v Ústa-

53 Dopis J. Chlumského uložen v EÚB, sign. X3/5/43.

54 Zpráva za rok 1937 dokonce hovoří o 80 zaslaných kontaktech. Viz Zprávy o činnosti MSV za léta 1936 a 1937. EÚB, sign. X7, fond SÚLP, složka Organizace II.

55 Zápis ze schůze MSV konané 20. prosince 1937. EÚB, sign. X7, fond SÚLP, složka Organizace II., rok 1937.

56 VÁCLAVEK, Beřich - SMETANA, Robert. České světské pisně zlidovělé: Část I. Písně epické. Svazek 1. Slovesný, hudebni a obrazový materiál pisni. Praha: ČSAV, 1955.

57 EÚB, sign. X7, fond SÚLP, složka Organizace II., rok 1936, zápisy ze schůzí MSV 4. května a 7. prosince 1936. Rukopis A. Gregora.

58 Podrobněji viz MOŽNÝ, Ivo. Bedřich Václavek jako sociolog masové kultury. Sociologický časopis, 1968, roč. $4(3)$, s. 362-371.

59 R. Smetana studoval u V. Helferta v letech 1924-1929, v roce 1934 obdržel doktorát na základě disertace $O$ hudebnich idiotismech v lidovém zpěvu evangeliků velkolhoteckých. Do SÚLP se hlásil s nabídkou spolu- 
vu ještě za Janáčkova života, společně s Václavkem se o to pokoušeli znovu v roce 1934. Jejich nabídku tehdy MSV přijal jednomyslně a toto doporučení bylo zasláno do Prahy. ${ }^{60}$ Již tehdy však docházelo k politizaci perzonálních otázek, o čemž nacházíme pasáž i v dopise Nejedlého Helfertovi. Z materiálu vyplývá, že přijetí Václavka bylo již v polovině 30. let komplikováno jeho levicovou orientací. I Nejedlý se v této situaci cítí být tím, kdo by „jen ještě škodil“, a o Václavkovi dále píše v dopise adresovaném Helfertovi: „Má právě vydávat Znárodnělé pisně [!], a tak tedy by snad šlo ho alespoň podepřit, aby ti páni nahoře viděli, že za ním někdo stojî."61 Helfert urgoval jmenování obou editorů v květnu 1937 na ústředí SÚLP. ${ }^{62} \mathrm{~V}$ případě Bedřicha Václavka lze sledovat nechut' k jeho jmenování kontinuálně. Ze zřejmých důvodů se tato nevůle po roce 1938 dále vystupňovala, a on se proto nikdy nestal členem SÚLP. ${ }^{63}$ Robert Smetana se dočkal kýženého členství teprve 14. května 1941.

Silnou výpovědní hodnotu má dopis B. Václavka adresovaný V. Helfertovi a datovaný 26. září 1938. ${ }^{64}$ Václavek a Helfert se v předzvěsti dramatických událostí dohodli, že rukopis sbírky zlidovělých písní bude uložen v sejfu Anglo-Pragobanky v Olomouci s dispozičním právem pro R. Smetanu a B. Václavka. Oním potvrzením bylo převedeno dispoziční právo na MSV pro případ, že by sami editoři nemohli rukopis vyzvednout. Uprostřed válečných událostí byla kopie rukopisu předána do sbírek Hudebního archivu Moravského zemského muzea v Brně. ${ }^{65}$

I když se B. Václavek nedožil otištění velkého společného díla (1955), zanechal literární a hudební vědě pozoruhodný odkaz, jehož součástí jsou i další publikace a studie připravované společně s R. Smetanou. Oba tak položili základ vědeckému poznání ve významné badatelské oblasti, která byla až do jejich nástupu ve dvacátých letech 20. století přehlížená a nedoceněná. ${ }^{66}$

práce na sbírce zlidovělých písní na doporučení Stanislava Součka už v listopadu 1927 (adresátem dopisu byl L. Janáček), dopisem 16. záríi 1933 nabídl ústavu svou sbírku písní z okolí Dačic (Velké Lhoty).

60 EÚB, sign. X7, fond SÚLP, složka Organizace II., rok 1935, nedatovaný zápis, rukopis A. Gregor, ante 2. března 1935 .

61 HANZAL, Josef. Zdeněk Nejedlý a Vladimír Helfert v dopisech. In Z bojů za českou hudebni kulturu, S. Zachařová (ed.), Praha: Academia, 1979, s. 165-273, zde s. 266-267. Dopis není datovaný, editoři jej přibližně umístili do období „po srpnu 1933“.

62 Dopis dat. 8. května 1937, EÚB, sign. X7, fond SÚLP, složka Organizace II., strojopis s vlastnoručními iniciálami V. H.

63 Ve zprávě MSV za období 1940-1946 se praví: „Mor.-sl. výbor vzpominá s hlubokým dojetím též tragické smrti dr. Bedřicha Václavka, statečného bojovnika za lepši prǐšti našeho národa, výborného znalce písni zlidovètých a kramáršských. Zesnulý nebyl sice naším členem, ale pracoval léta společněs námi. Vzrušené události v l. 1938-1939 zabránily, že ministerstvo školstvi a národni osvěty náš návrh na jeho jmenováni členem Mor-slezského výboru už kladně nevyř́dilo." MÚ-AAV, fond SÚLP, kart. 29, inv. č. 502; dat. 26. 9. 1946, rukopis A. Gregora.

64 Dopis B. Václavka adresovaný V. Helfertovi, datovaný 26. září 1938. EÚB, korespondence sign. B4, složka B. Václavek.

65 Tamtéž je uloženo potvrzení o převzetí sbírky do depozita Moravského zemského muzea, datované 22. února 1940. Vystavil je Jan Racek při převzetí kopie sbírky.

66 VÁCLAVEK, Bedřich - SMETANA, Robert. Český národni zpěvnik. Písně české společnosti 19. století. Praha: Melantrich, 1940. Titíž. O české pisni lidové a zlidovèté. Praha: Svoboda, 1950 aj. 


\section{Za okupace}

Podobně jako tomu bylo u dalších institucí, byla činnost SÚLP za okupace ochromena. Negativní tendence se objevovaly v mnoha parametrech již v období na sklonku předmnichovské republiky. V roce 1938 se MSV pod Helfertovým vedením sešel třikrát 25. dubna, 20. června a 14. řijna $1938 .{ }^{67} \mathrm{~V}$ průběhu roku se projednávaly věci spojené s nákupem a získáváním sbírek, záležitost rukopisu zlidovělých písní, návrh Josefa Černíka na pořízení mapy sběrů. Také se jednalo o návratu Hynka Bíma ze Slovenska, kde se od roku 1938 projevovaly fašizující tendence a členové Slovenského výboru, kteří byli české národnosti, se vraceli do Prahy a do Brna. Přesto ještě členové MSV věřili v blízký rozvoj terénních aktivit, jak o tom hovoří zpráva za rok 1938, která vysoce hodnotila dříve zmiňovanou akci zaměřenou na obnovení sítě sběratelů: „Je třeba míti za to, že na tomto širokém základě bude míti naše sběratelská akce žádouci úspěch." ${ }^{8}$

Události spojedné s Mnichovskou dohodou ale učinily konec všem plánům na systematickou a státem podporovanou práci. Dne 24. dubna 1938 se konal sjezd Sudetoněmecké strany v Karlových Varech, kde Konrad Henlein vyhlásil program, obsahující mj. návrh na okleštění území Československa. V žádných oficiálních dokumentech např́íště nenajdeme vyjádření SÚLP směřovaná k tehdejší politické situaci. Z období mezi vyhlášením Karlovarského programu a podpisem Mnichovské dohody je zřejmě moment, kdy se výbor pod Helfertovým vedením hodlal vyjádřit k chystanému německému záboru Břeclavska. Svědčí o tom náčrt psaný rukou Helfertovou. Tento text, pokud by vůbec někdy dostal podobu oficiálního stanoviska, by musel být bez pochyby v době Protektorátu $\mathrm{z}$ dokumentace odstraněn:

„Vzhledem ke stanoveni konečné hranice na jižni Moravě dovoluje si Mor.-slez. výbor upozorniti, že Břeclav s okolim patři po stránce národního rázu moravského, jak se jevi v lidové pisni k výrazným mor. končinám, že je těžko myslitelné, že by tento kraj měl být zabrán německou ř́ší. Vynikajici badatelé souhlasně označuji Břeclavsko za národopisně nejsvéráznějši kraj moravský. Znamenalo by těžkou kulturni škodu, kdyby měl právě tento kraj být ztracen. "69

V dubnu a prosinci 1938 Horák s Helfertem řešili otázku honoráře za přípravu Moravských písní milostných, ${ }^{70}$ na jaře příštího roku již byla aktuální otázka reorganizace celého ústavu. Po nastolení Protektorátu byl v Bratislavě oficiálně zrušen Slovenský výbor. Jak psal J. Horák v dopise V. Helfertovi 14. dubna 1939, počítalo se s tím, že Německý výbor bude „[...] pričleněn $k$ obdobným institucím řišským. Proto jsem napsal předsedovi němec-

67 Všechny zápisy schůzí MSV od prosince 1937 do roku 1939 mají atypickou podobu strojopisu bez rukopisných poznámek a podpisů, jsou psány ve shodné úpravě, na stejném psacím stroji a stejném papíře. Mají jen strojopisný podpis Č. Gardavského, jsou maximálně stručné a s největší pravděpodobností se jedná o náhradní materiály vytvořené v souvislosti se zatčením V. Helferta. Jeho jméno figuruje jen na seznamu přítomných a v projednávaných budech se vůbec neobjevuje.

68 EÚB, sign. X7, fond SÚLP, složka Organizace II., rok 1938.

69 EÚB, sign. X7, fond SÚLP, složka Organizace II., rok 1937, 1 f., nedat., rukopis Helferta, zde přepsáno v definitivní verzi bez škrtů.

70 MZM-ODH, pozůstalost V. Helferta, dopisy z 1. 4. 1938, sign. D 399; 17. 12. 1938, sign. D 400. 
kého výboru prof. Jungbauerovi, aby uvažoval o nové organizaci německého výboru, který by se stal ústavem zcela samostatným a organisačně neměl s výbory českými nic společného. "71

Tyto záležitosti J. Horák naznačoval V. Helfertovi již v dopise 9. března, když předtím věci projednal se Z. Nejedlým a diskutoval o nich individuálně na Ministerstvu školství a národní osvěty. Helferta požádal o svolání brněnského výboru a sdělení usnesení. Ten tak učinil a po schůzi 8. května 1939 mohl 12. května Horákovi odpovědět, že MSV s návrhem na reorganizaci souhlasí.

Z materiálů není vůbec zřejmé, zda se Hlavní výbor sešel v Praze na schůzi i na jaře 1939. Dne 14. listopadu 1939 byl Vladimír Helfert zbaven profesury a zatčen gestapem.

Dokumentace dál hovoří jen o schůzi Hlavního výboru 8. června 1940, kde bylo obnoveno složení výborů tak, aby se zamezilo možným negativním dopadům na činnost SÚLP. Na základě dřívějšího doporučení Helferta byl předsedou MSV zvolen Alois Gregor. $^{72}$ Po Helfertově zatčení jeho jméno z materiálů SÚLP naprosto vymizelo. Mohlo se objevit až v retrospektivní zprávě o činnosti MSV za období 1940-1945, v textu předsedy A. Gregora, který v nejvyšší úctě vzpomněl svého předchůdce:

„Přretěžkou ztrátu utrpěl náš výbor úmrtím prof. dr. Vlad. Helferta 18. května 1945. Opustil nás ve chvili, kdy se celý náš národ těšil upř́mně ze svobody po tak těžkém utrpeni nabité, ve chvíli, kdy bylo tolik zapotřebi zanicených, energických a rozšafných mužü, jako byl on. Toužebně jsme čekali, že se zase ujme vedeni v našem výboře, nebot’ tam byl vpravdě dưstojný nástupce prof. dr. Stanislava Součka a bez nadsázky jeho duší. Poskytl nám velmi ochotně pohostinství $v$ mistnostech semináre pro hud. vědu přri Masarykově universitě. U něho jsme měli umístěny své sbirky, u něho jsme konali své schůze. On príbíral k práci v našem výboře některé ze svých posluchačů, kteři měli o lidovou poesii zájem, tak zejména Čeňka Gardavského. Zachováme mu poprávu nejkrásnějši vzpomínku i jako vzácnému člověku, v dějinách našeho výboru $i$ nepochybně celého ústavu bude mu patřit vždycky jedno z nejčestnějších mist." "73

\section{Závěrem}

Ačkoliv by výše uvedený citát mohl náš text ukončit, nabízí se znovu podtrhnout některé významné momenty charakterizující Helfertova stanoviska a přístupy k dané tematické oblasti. V první řadě je nutno zdo̊raznit mnohovrstevnatost a komplexnost Helfertova zájmu o hudební kulturu, který se projevuje napříč všemi žánry a který má základ v rodinné tradici. Jeho nadčasový př́istup k problémům hudební folkloristiky byl daný mimořádným hudebně-estetickým vzděláním a cítěním a v prvních desetiletích 20. století byl podmíněn definitivním překonáním názoru, že se lidová píseň ztrácí současně se zánikem tradičního životního stylu. Dynamické pojetí lidové písně, které Helfert bezpochyby

71 MZM-ODH, dopis z 14. 4. 1939, sign. D 401. Helfert si na dopis poznamenal: Odp. 14. IV. 39: „souhlasim / Budu v Praze a věci projednáme."

72 MÚ-AAV, fond SÚLP, kart. 29, inv. č. 500. Gregor tento úkol zastával až do roku 1948, kdy po komunistickém převratu dopisem z 24. června 1948 ze své vůle abdikoval.

73 MÚ-AAV, fond SÚLP, kart. 29, inv. č. 502, zpráva MSV za období 1940-1945, dat. 26. 9. 1946, rukopis A. Gregora. 
převzal od Otakara Hostinského, bylo teoretickou oporou pro trvalý a znovu probuzený zájem o situaci v terénu a o evidenci výsledků zasahující všechny písňové druhy. Do práce ve SÚLP Helfert vnesl kritický přístup k pramenům a smysl pro jejich systematické a vědecké zpracování. Nanejvýš zajímavé je zjištění, že první kroky v tomto směru vykonával společně s Leošem Janáčkem, což také může vysvětlovat vědcovu zásadní proměnu a názorový posun při hodnocení Janáčkova uměleckého fenoménu. K folkloristické práci přivedl řadu talentovaných studentů ze Semináře pro hudební vědu Masarykovy univerzity, z nichž se mnozí později v dané badatelské oblasti profilovali jako autority a vzory pro příští generace. Podobně jako další členové SÚLP, většinu organizačních aktivit Helfert dělal bez nároku na finanční odměnu, v př́padě Morauských písni milostných se jeho jméno neobjevilo ani na titulní straně edice. Svoje snažení na tomto poli vždy vykonával $\mathrm{s}$ vědomím širších souvilostí a s pokorou.

Studie vznikla v rámci projektu GA ČR č. 16-14263S.

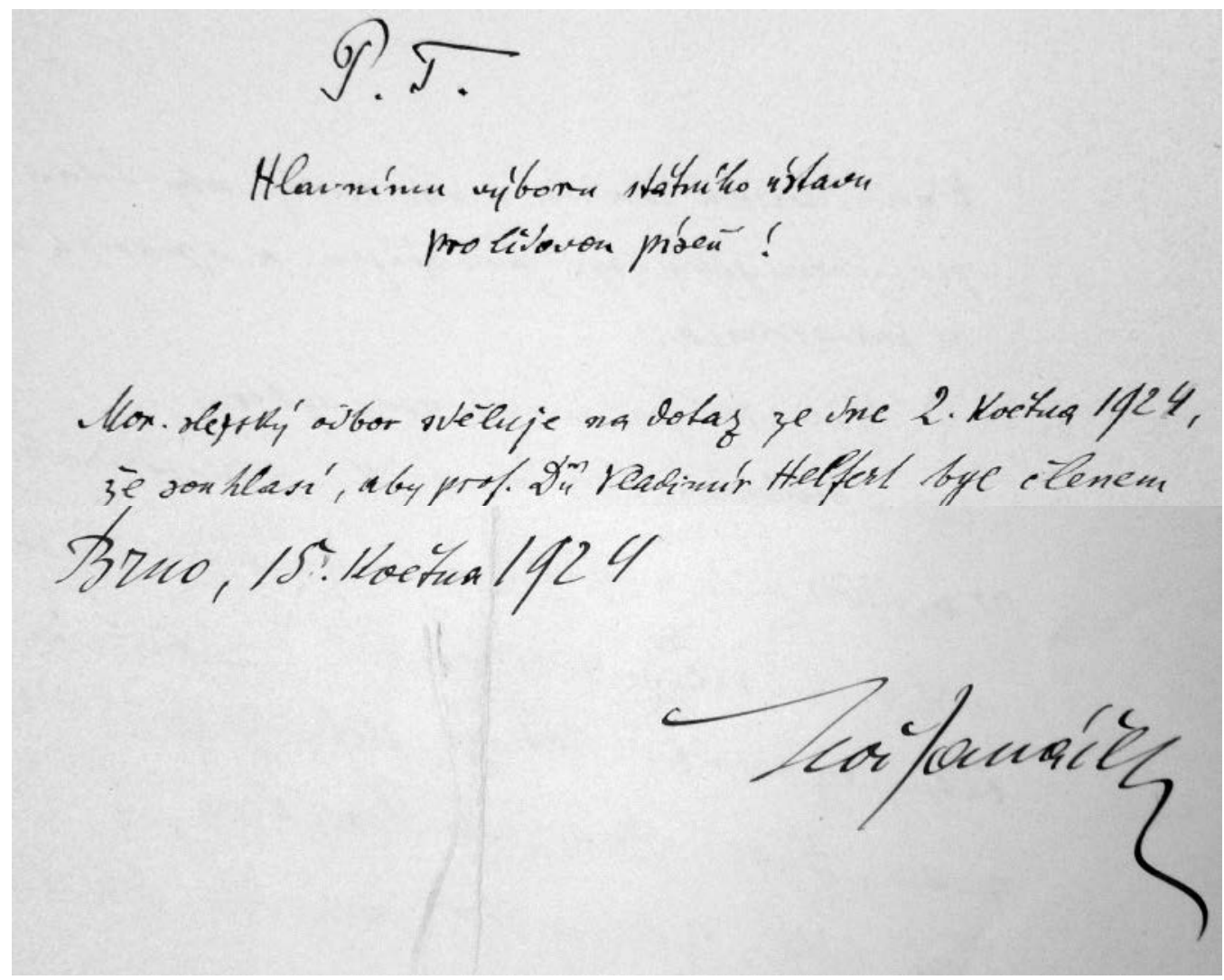

Obr. 1. Janáčkovo potvrzení zájmu o členství Vladimíra Helferta v Moravsko-slezském výboru SÚLP. Zdroj: Mú-AAV, fond SÚLP, inv. č. 476. 


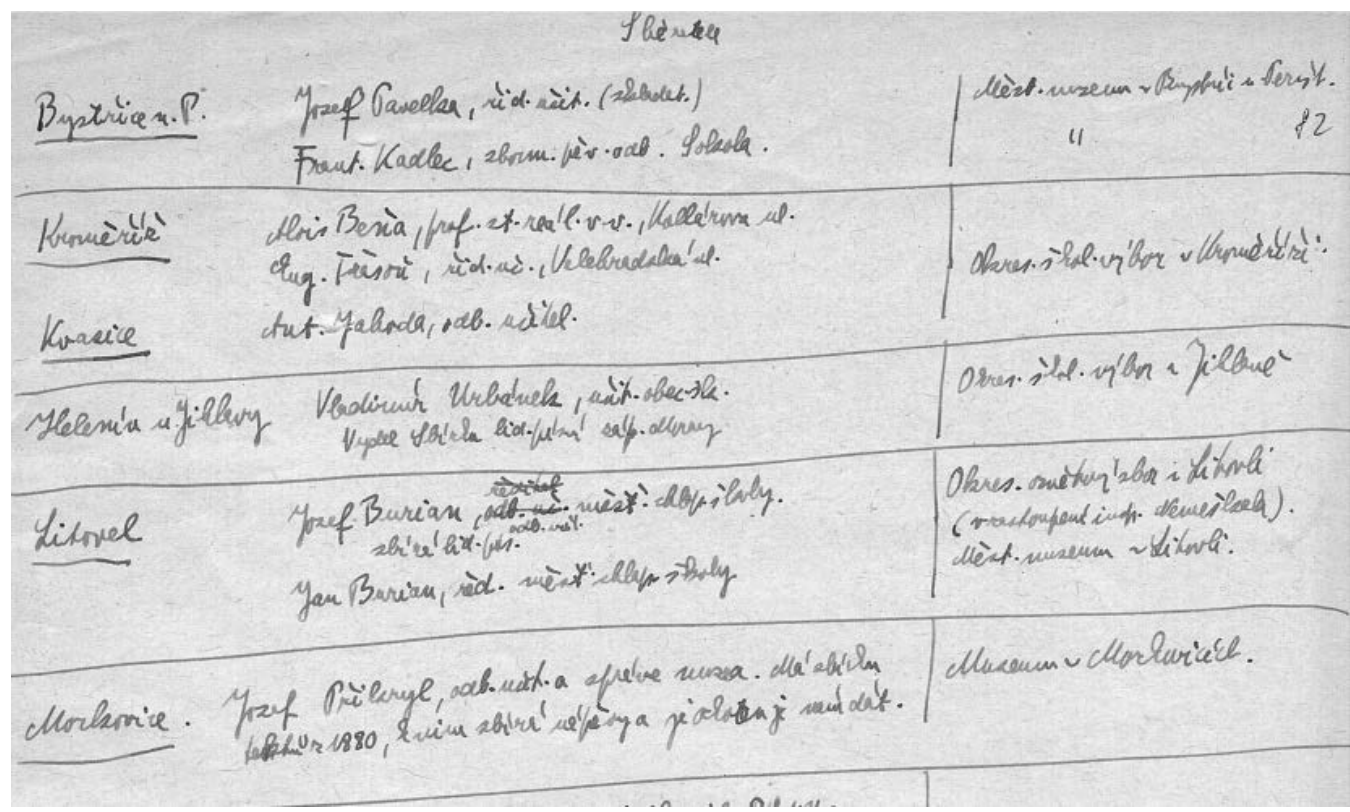

Obr. 2. Začátek Helfertova soupisu nových sběratelů spolupracujících se SÚLP. Zdroj: EÚB, sign.-x3-4-82.

\section{Bibliography}

\section{Sources}

Moravské zemské muzeum, Brno, fond pozůstalost V. Helferta, korespondence (sign. A), studie (sign. S).

Masarykův ústav - Archiv Akademie věd, Praha, fond Státní ústav pro lidovou píseň.

Etnologický ústav Akademie věd České republiky, v.v.i., Praha, sbírky pracoviště Brno.

\section{Literature}

HANZAL, Josef. Zdeněk Nejedlý a Vladimír Helfert v dopisech. In Z bojů za českou hudebni kulturu, S. Zachařová (ed.), Praha: Academia, 1979, s. 165-273.

HELFERT, Josef Alexander - HOSTINSKÝ, Otakar. Volkslied und Tanz der Slaven. In Die Oesterreichisch-ungarische Monarchie in Wort und Bild: Böhmen (1. Abtheilung). Wien: Verlag der kaiserisch-königlichen Hof- und Staatsdruckerei, 1894, s. 462-482.

HELFERT, Vladimír. Contributo alla storia della „Marseillaise“. Rivista musicale italiana. Torino: Bocca; 1922, s. 622-638.

HELFERT, Vladimír. K otázce našeho hudebního folkloru. Morava, měsičnik pro život sociálni, vědecký a umělecký, 1925, roč. 1, s. 230-236. 
[HELFERT, Vladimír] V. H. Poměrem mad’arské lidové písně k slovenské se zabývá Béla Bartók “ [...], Časopis Matice moravské, 1937, roč. 61, s. 455-457.

HOLÝ, Dušan. Metodologický př́nos Vladimíra Helferta pro studium hudebního folkloru. In Vladimír Helfert v českém a evropském kontextu, R. Pečman (ed.) Brno: Svaz českých skladatelů a koncertních umělců, 1987, s. 31-34.

HRABALOVÁ, Olga. K dějinám hudebněfolkloristického bádání na Moravě. Národopisné aktuality, 1982, roč. 19, č. 3, s. 169-178.

CHLUMSKÝ, Josef. Fonografický a gramofonový archiv České akademie věd a umění. Časopis pro moderni filologii, 1930, roč. 16, s. 189-192.

JANÁČEK, Leoš - VÁŠA, Pavel. Moravské pisně milostné. I. Praha: SÚLP, Orbis, 1930-1936 [1937].

KRATOCHVÍL, Matěj. Úvod. In Lidová hudba v Československu (Nahrávky Fonografické komise České akademie věd a umění) 1929-1937, ed. M. Kratochvíl. Praha: Etnologický ústav AV ČR, v.v.i., 2009, s. 22-42.

MOŽNÝ, Ivo. Bedřich Václavek jako sociolog masové kultury. Sociologický časopis, 1968, roč. 4(3), s. 362-371.

PAVLICOVÁ, Martina. Z historie Státního ústavu pro lidovou píseň v Brně v meziválečném období. In Od Pracovního výboru pro českou národni píseñ na Moravě a ve Slezsku k Ústavu pro etnografii a folkloristiku 1905-1995, L. Uhlíková (ed.) Brno: Akademie věd České republiky, 1995, s. 24-29.

PEČMAN, Rudolf. Vladimír Helfert. Brno: Nadace Universitas Masarykiana, Edice Osobnosti, 2003 POLEDŇÁK, Ivan. Soupis prací Vladimíra Helferta. In Musikologie sv. 5, Praha 1958, s. 253-313.

PROCHÁZKOVÁ, Jarmila. Bartók's Attempt at Cooperation with the State Institute for Folk Song in Czechoslovakia and Its Political Connotations. Hudebni věda, 2016, roč. 52, č. 1, s. 73-90.

SMETANA, Robert. V práci pro lidovou píseň. Index, 1936, roč. 8, č. 3, s. 30-32.

SMETANA, Robert. Za Vladimírem Helfertem. In Vladimír Helfert: pokrokový vědec a člověk. Studie, korespondence a vzpominky. Zvläštni př́loha Sborniku praci filosofické fakulty brněnské univerzity, H 9 , Brno 1975, s. 63-67.

VÁCLAVEK, Beřich - SMETANA, Robert. České světské pisně zlidovělé: Část I. Písně epické. Svazek 1. Slovesný, hudebni a obrazový materiál pisni. Praha: ČSAV, 1955.

VÁCLAVEK, Bedřich - SMETANA, Robert. Český národni zpěvnik. Písně české společnosti 19. století. Praha: Melantrich, 1940.

VÁCLAVEK, Bedřich - SMETANA, Robert. O české pisni lidové a zlidovělé. Praha: Svoboda, 1950.

VETTERL, Karel - GELNAR, Jaromír. Nad katalogy písňových nápěvů. Český lid, 1962, roč. 49, s. 241-249.

VYSLOUŽIL, Jiří. K organisaci hudebně lidopisného bádání na Moravě a ve Slezsku. In Musikologie sv. 2, Praha - Brno - Bratislava: Svaz československých skladatelů, 1949, s. 214-220.

VYSLOUŽIL, Jiří (ed.). Leoš Janáček, O lidové pisni a lidové hudbě: dokumenty a studie. Praha: Státní nakladatelství krásné literatury, hudby a umění, 1955. 